\title{
Relevant phosphoproteomic and mass spectrometry: approaches useful in clinical research
}

\author{
Elena López ${ }^{1,2^{*}}$, Sarbelio Rodríguez Muñoz², Juan López Pascual ${ }^{2}$ and Luis Madero ${ }^{1,3^{*}}$
}

\begin{abstract}
Background: "It's not what we do, it's the way that we do it". Never has this maxim been truer in proteomics than now. Mass Spectrometry-based proteomics/phosphoproteomics tools are critical to understand the structure and dynamics (spatial and temporal) of signalling that engages and migrates through the entire proteome. Approaches such as affinity purification followed by Mass Spectrometry (MS) have been used to elucidate relevant biological questions disease vs. health. Thousands of proteins interact via physical and chemical association. Moreover, certain proteins can covalently modify other proteins post-translationally. These post-translational modifications (PTMs) ultimately give rise to the emergent functions of cells in sequence, space and time.

Findings: Understanding the functions of phosphorylated proteins thus requires one to study proteomes as linkedsystems rather than collections of individual protein molecules. Indeed, the interacting proteome or proteinnetwork knowledge has recently received much attention, as network-systems (signalling pathways) are effective snapshots in time, of the proteome as a whole. MS approaches are clearly essential, in spite of the difficulties of some low abundance proteins for future clinical advances.

Conclusion: Clinical proteomics-MS has come a long way in the past decade in terms of technology/platform development, protein chemistry, and together with bioinformatics and other OMICS tools to identify molecular signatures of diseases based on protein pathways and signalling cascades. Hence, there is great promise for disease diagnosis, prognosis, and prediction of therapeutic outcome on an individualized basis. However, and as a general rule, without correct study design, strategy and implementation of robust analytical methodologies, the efforts, efficiency and expectations to make biomarkers (especially phosphorylated kinases) a useful reality in the near future, can easily be hampered.
\end{abstract}

Keywords: Phosphoproteomics, Mass spectrometry, Clinical research

\section{Findings}

\section{Overview}

Proteomics and phosphoproteomics clinical research studies imply the comprehensive analysis of the proteins which are expressed in cells or tissues, and can be employed at different stages (e.g. healthy $v s$. disease). Therefore, comparative proteomics can distinguish small, but relevant changes in protein modifications in their structure -post-translational modifications (PTMs)-

\footnotetext{
* Correspondence: elena.lopez.villar@gmail.com; Imadero.hnj@salud.madrid. org

${ }^{1}$ Hospital Universitario Infantil Niño Jesús, Av. Menéndez Pelayo 65, 28009 Madrid, Spain
}

Full list of author information is available at the end of the article at a depth of several thousand proteins to facilitate drug target identification.

Chemical and Biochemical proteomics can be used to identify drug-target interactions and subsequently analyze drug specificity and selectivity. Furthermore, phosphoproteomic approaches can be exploited to monitor changes in phosphorylation events in order to characterize drug actions on cell signalling pathways and/or signalling cascades. In addition, functional proteomic approaches, can be employed to investigate protein-protein and protein-ligand interactions in order to: (i) improve the knowledge or the clarification of the mechanism of drug action, (ii) achieve relevant protein-

\section{实 Springer}

(C) 2012 López et al; licensee Springer. This is an Open Access article distributed under the terms of the Creative Commons Attribution License (http://creativecommons.org/licenses/by/2.0), which permits unrestricted use, distribution, and reproduction in any medium, provided the original work is properly cited. 
identifications of disease-related sub-networks and (iii) reach the important step of innovation of novel drug targets.

Furthermore, proteins are currently the major drug targets, and therefore play a critical role in the process of modern drug design. This typically involves: (1) the construction of drug compounds based on the structure of a specific drug target, (2) validation for therapeutic efficacy of the drug compounds, (3) evaluation of drug toxicity, and finally, (4) clinical trial.

Finally, tissue imaging MS is being extended as a current promising technique for reproductive research. Advances in MS imaging will inevitably attract biologists and clinicians as the advantages and power of this technology become more widely known. We will detail, in a simple manner, relevant clues of current proteomic, phosphoproteomic and MS strategies and techniques useful for clinical advances [1].

\section{Phosphoproteomics relevance in signalling transduction pathways}

It is well known that phosphoproteomics and MS-based recent advancements have made these approaches the ideal way by which to study signal transduction although it implies high speciality and tedious research studies. In addition, individual protein phosphorylation events often have important roles and clues in broad signalling networks within a cell. Unfortunately, while phosphorylation of kinases frequently, mainly regulates their own activity, they are commonly under-represented in phosphoproteomic studies, partly due to their low expression within the cell. Nevertheless, a viable solution to this drawback has been successfully proven via kinase affinity purification techniques. Thus, important improvements are helping to achieve relevant data of phosphorylated kinases - those proteins being the "key" of signalling pathways and network- connectivity among different signalling cascades.

Phosphatases are playing equally important roles in regulating signalling pathways through the removal of phosphoryl groups from proteins. Indeed, depleting cells of specific protein phosphatases and employing phosphoproteomic approaches, can be used to determine which proteins are regulated by the phosphatase of interest, either directly or downstream [2-7].

The best studies of mitogen activated protein kinase (MAPKs) are the extracellular signal regulated protein kinases (ERK). ERKs phosphorylate cytoplasmic targets migrate to the nucleus where they can activate transcription factors involved in cellular proliferation. As a general view of the orchestrated signalling pathways, it is important to know that following the communication of the signal to different cellular compartments are (1) signal processing and (2) amplification by plasma membrane proximal events.
The activation of multiple signal cascades by (1) receptors, (2) different protein PTMs, (3) crosstalk between signalling pathways and (4) feedback loops to ensure optimal signalling output, are involved in this process. Also, the binding of receptor Tyrosine (Tyr) kinases (RTKs) to their cognate ligands at the cell surface results in receptor dimerization and autophosphorylation. Phosphorylated Tyr residues subsequently serve as docking sites to recruit signalling mediators, such as growth factor receptor-bound protein 2 (GRB2).

Multiple signalling cascades such as (1) the phosphoinositide-3 kinase (PI3K)-AKT, (2) Ras-Raf- extracellular signal-regulated kinase (ERK) mitogen-activated protein kinase (MAPK), and (3) signal transducer and activator of transcription (STAT) pathways are activated by the assembly of these signalling complexes. On the other hand, (4) Casitas B-lineage lymphoma (CBL)-mediated ubiquitylation of RTKs controls their endocytosis and the duration of receptor signalling. In addition, binding of tumour necrosis factor- $\alpha$ (TNF $\alpha$ ) to its receptor, TNFR1, induces trimerization of the receptor and recruitment of the adaptor protein TNFR1-associated death domain (TRADD). These functions as a hub to assemble a multi-protein signalling complex containing TNFR-associated factor 2 (TRAF2), receptor interacting Ser/Thr protein kinase 1 (RIPK1) and nuclear factor- $\kappa \mathrm{B}$ $(\mathrm{NF}-\kappa \mathrm{B})$ essential modulator (NEMO). The result is the activation of different signalling networks, such as the ERK MAPK, p38 MAPK and NF- $\kappa$ B pathways. Proteins in the MAPK signalling pathways are activated by both RTKs and TNF $\alpha$, which allows cells to integrate multiple signals [8-20].

\section{Advantages/disadvantages and clues of most used MS- based tools for the detection of phosphorylated proteins/ peptides}

Several analytical techniques exist for the analysis of phosphorylation, e.g., Edman sequencing and ${ }^{32} \mathrm{P}$-phosphopeptide mapping for localization of phosphorylation sites, but these methods do not allow high-throughput analysis or imply very laborious operations [21], while using MS, high-throughput analysis of phosphorylated protein residues can be developed [22,23]. On the other hand, phosphospecific antibodies are routinely used to immunoprecipitate and therefore to enrich in phosphorylated proteins from complex mixtures [24], but, currently, there are no antibodies available commercially suitable for enriching all proteins that are phosphorylated, and thus, these proteins must be purified or enriched from complex mixtures using alternative methods [25].

When carrying out in-gel or in-solution trypsin digestion of protein complex mixtures, the resulting phosphopeptides and non-phosphopeptides can be loaded into different metal ion chromatographies (e.g. 
Immobilized Metal ion Affinity Chromatography IMAC $\left(\mathrm{Fe}^{3+}\right)$, and Titanium Dioxide $\left.\mathrm{TiO}_{2}[26]\right)$ in order to enrich in phosphopeptides. The enriched solution can also be submitted into different reverse-phase chromatographies (e.g. Graphite powder [27], POROS R3) [25] in order to clean and desalt those phosphopeptides previously eluted. Moreover, all these types of chromatographies will reduce the suppression of phosphorylated peptides in the mass spectra.

Using IMAC $\left(\mathrm{Fe}^{3+}\right)$ and also $\left(\mathrm{TiO}_{2}\right)$ [26], the negatively charged phosphopeptides are purified by their affinity to positively charged metal ions, but some of these methods suffer the problem of binding acidic, non-phosphorylated peptides. Ficarro and co-workers [22], circumvented this problem on IMAC $\left(\mathrm{Fe}^{3+}\right)$ by converting acidic peptides to methyl esters but increasing the spectra complexity and requiring lyophilization of the sample, which causes adsorptive losses of especially phosphopeptides [28]. Ficarro et al., were able to sequence hundreds of phosphopeptides from yeast, including Slt2p kinase, but the level of phosphorylated residues identified from kinases were low compared to the ones from phosphoproteins highly expressed within the cell. Fairly recently, $\mathrm{TiO}_{2}$ chromatography using 2,5dihydroxybenzoic acid (DHB) was introduced as a promising strategy by Larsen et al. [26],. $\mathrm{TiO}_{2} / \mathrm{DHB}$ resulted in higher specificity and yield as compared to IMAC $\left(\mathrm{Fe}^{3+}\right)$ for the selective enrichment of phosphorylated peptides from model proteins (e.g. lactoglobulin bovine, casein bovine, etc).

Another important limitation concerning the phosphoenrichment methods is that mainly phosphopeptides from highly expressed proteins within cells can be purified, while the ones from phosphorylated proteins with low level expression (e.g. kinases) do not bind so well to those resins. This is due to the low proportion of this kind of proteins, or on the other hand, their available amount binds to metal ions although it is not sufficient to be detected by MS. The combination of Strong Cation Exchange Chromatography (SCX) with IMAC $\left(\mathrm{Fe}^{3+}\right)$ has been proven on yeast, resulting in a huge number of phosphorylated residues identified (over 700, including Fus3p kinase) [23]. Although more than 100 signalling proteins and functional phosphorylation sites were identified, including receptors, kinases and transcription factors, it was clear that only a fraction of the phosphoproteome was revealed [23].

It is evident that methodologies to enrich for phosphorylated residues from kinases should be improved. However, this is not straightforward for several reasons: (a) the low abundance of those signalling molecules within cells, and (b) the stress/stimulation time-duration, as only a small fraction of phosphorylated kinases are available at any given time as a result of a stimulus.
Also, the time adaptation over signalling pathways is a relevant and fast factor for kinases phosphorylation [29], and (c) the current phosphoenrichment methods, which are mainly successful to purify phosphopeptides from highly expressed proteins.

In a simple manner, we will detail the manual validation of the phospho-data (assignments of the phosphate group on specific amino acids) obtained in an MS experiment during CID (Collision Induced Dissociation) operations. When peptide ions are fragmented via CID, series of $y$ - and $b$-ions are formed [30,31]. The peptide sequence is obtained by correlating mass difference between peaks in the $y$-ion series or between peaks in the $b$-ion series with amino acid residue masses. The CID fragmentation mainly occurs on the peptide backbone, and sequence information is obtained. In relation to phosphotyrosine residues, partial neutral loss is observed $\left(\mathrm{HPO}_{3}, 80 \mathrm{~m} / \mathrm{z}\right)$ in MS2 mode, and the phosphate group on tyrosine (Tyr) residues is more stable than on serine (Ser) and threonine (Thr) residues. Also, the phospho-finger-print characteristic of phosphotyrosine is the phosphotyrosine immonium ion $(\sim 216 \mathrm{Da})$ $[32,33]$. Via MS3 mode, the ion originating from neutral loss $(\mathrm{NL})$ of phosphoric acid $\left(\mathrm{H}_{3} \mathrm{PO}_{4}\right)$ can be selected for further fragmentation. Then, the selected ion is automatically selected for further fragmentation after neutral loss fragmentation. Therefore, it is possible to add extra energy for the fragmentation of peptide backbone.

Nevertheless, the MS3 mode requires that the phosphorylation on Ser and Thr residues are labile and conventional fragmentation via CID commonly resulting in the partial NL of $\mathrm{H}_{3} \mathrm{PO}_{4},(98 \mathrm{~m} / \mathrm{z})$ in MS2 mode. This is due to the gas phase $\beta$-elimination of the phosphorester bond and thus, dehydroalanine (Ser $\sim 69 \mathrm{Da}$ ) and dehydro-2-aminobutyric acid ( $\mathrm{Thr} \sim 83 \mathrm{Da}$ ) are generated $[32,33]$.

In addition, as alternative phosphopeptide enrichment strategies, phosphopeptides can be de-protected and collected under acidic conditions and a variety of chemical methodologies have likewise appeared. BEMA ( $\beta$-elimination/Michael addition), takes advantage of the ease of $\beta$-elimination of phosphorylated Ser and Thr residues at basic $\mathrm{pH}$ and the ability to subject the resulting dehydroalanine/methyl-dehydroalanine products to Michael addition with a desired tag for affinity purification [34-36]. In addition, Calcium phosphate precipitation (CPP) has been proven to be a fast, economical, and simple enrichment technique [37] in exchange for diminished specificity. Moreover, PhosphorAmidate Chemistry (PAC) is another important approach in which phosphopeptides are coupled to a solid-phase support such as an amino-derivatized dendrimer or controlled-pore glass derivatized with maleimide for selection $[38,39]$. 


\section{Tandem MS Methodology -basic issues useful for} Phosphoproteomics via ElectroSpray lonization (ESI)

It can be taken as a general rule, that during MS-based experiments, a phosphopeptide mixture is separated using capillary liquid chromatography (LC). A typical separation column is 25 to 100 microns in diameter and 5 to $30 \mathrm{~cm}$ in length. The eluent is concurrently introduced into the mass spectrometer via electrospray ionization (ESI). ESI is a process that generates multiply protonated gas-phase peptide cations. The mass-tocharge ratio $(\mathrm{m} / \mathrm{z})$ and intensity $(I)$ of the intact peptide precursors are recorded by an initial MS scan - commonly referred to as a full scan MS. Then, $m / z$ values for peaks (list of masses) with high intensity are automatically selected in order of decreasing abundance for sequencing by tandem MS (MS/MS). This process of precursor selection, dissociation, and fragment ion mass analysis is repetitively performed on analyte species as they elute from the LC column. Ideally, MS/MS interrogation of a phosphorylated peptide generates a series of fragment ions that differ in mass by a single amino acid, so that the peptide primary sequence and position of the phosphorylated modifications can be determined. This necessitates peptide bond cleavage that is not only specific to the peptide backbone, but is robust enough to elucidate differences in peptides whose primary amino acid sequence are the same, yet vary in the site of phosphorylation (e.g., positional isomers) [40]

The dominant NL peak in the fragmentation spectra of phosphopeptides obtained via traditional collisionally induced dissociation (CID) has received much attention [41-43]. The NL peak can easily suppress sequence diagnostic ion peaks causing identification of the peptide to become extremely difficult and sometimes impossible.

Since the use of ion traps, currently, as the most common mass spectrometers of performing phosphoproteome analyses, there have been various attempts to combat this specific problem. Modified fragmentation regimes have been introduced, such as (a) NL triggered MS3 or (b) multistage activation (MSA), which alleviate the neutral loss issue. NL MS3 and MSA methods allow fragmenting of the NL peak of the precursor ion further, in order to generate more backbone cleavages. These "extra" generated backbone cleavages, then form more diagnostic sources for peptide sequencing [23,44-46].

Alternatively, Electron transfer dissociation (ETD) and electron capture dissociation (ECD) have also shown great promise since the phosphate group remains attached during and after activation. Many detected phosphopeptides contain multiple Ser/Thr/Tyr (serine, threonine, and tyrosine) residues representing the likelihood that there is more than one possible location for the site of phosphorylation within the peptide. The abundant NL observed in low energy CID can hamper the correct assignment of the phosphor-sites in such peptides. Thus, a concerted effort has been made to understand, in detail, the rules of phosphopeptide fragmentation [47-51]. Figures 1 and 2 illustrate the flowthrough to identify proteins via proteomics-MS, and different phosphoproteomic strategies to ensure high efficiency for clinical research study, respectively.

\section{Discovering Biomarkers via OMICS Tools}

MS-based proteomics technologies are capable of identifying hundreds to thousands of proteins in cells, tissues, and biofluids. Proteomics may, therefore, provide the opportunity to elucidate new biomarkers and pathways without a prior known association with a specific disease. However, important obstacles remain.

Additionally, improved biomarkers are of vital importance for cancer detection, diagnosis and prognosis. Significant advances in understanding the molecular basis of disease are being made in genomics, while proteomics will ultimately delineate the functional units of a cell: proteins and their intricate interaction networks and signalling pathways in health and disease. Much progress has been made to characterize thousands of proteins qualitatively and quantitatively in complex biological systems by use of multi-dimensional sample fractionation strategies, MS and protein micro-arrays. Comparative/quantitative analysis of high-quality clinical biospecimen (e.g., tissue and biofluids) of the human cancer proteome landscape can potentially reveal protein/peptide biomarkers responsible for this disease by means of their altered levels of expression, PTMs as well as different forms of protein variants. Despite technological advances in proteomics, major hurdles still exist at every step of the biomarker development pipeline [52-63].

The field of proteomics, in the post-genome era, incited great interest in the pursuit of protein/peptide biomarker discovery especially since MS demonstrated the capability of characterizing a large number of proteins and their PTMs in complex biological systems, in some instances even quantitatively. Technological advances, such as protein/antibody chips, depletion of multiple high abundance proteins by affinity columns, and affinity enrichment of targeted protein analytes, as well as multidimensional chromatographic fractionation, have all expanded the dynamic range of detection for low abundance proteins by several orders of magnitude in serum or plasma, making it possible to detect the more abundant disease-relevant proteins in these complex biological matrices [63-71]. Nevertheless, plasma and cell-extract based discovery research studies aimed at identifying low abundance proteins (e.g. some kinases) are extremely difficult. Therefore, it is necessary to develop significant technological improvements related to identifying these low abundance, yet high biological 


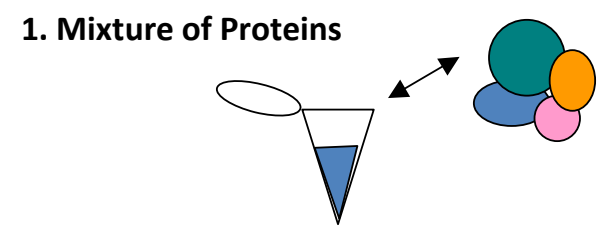

\section{Separation of Proteins \\ $>$ Via 1D o 2D PAGE Gels \\ $>$ Via Solution}

$\mathrm{kDa}$

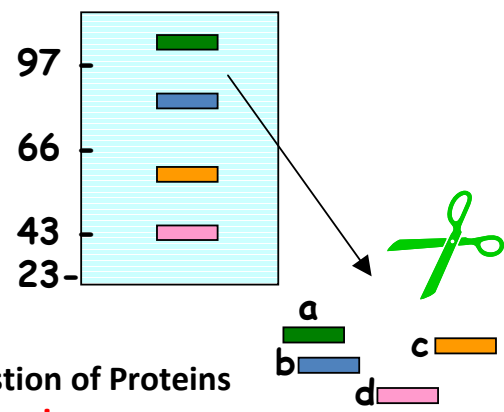

3. Digestion of Proteins

(e.g) Trypsin

$\square \square \square \quad \square \square \square \quad \square \square \square \quad \square \square \square$

Obtaining mixture of peptides
4. Desalting and Cleaning peptides (Chromatography)

Salts, Detergents, Keratins

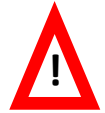

5. Analysis of peptides via Mass Spectrometry (MS)

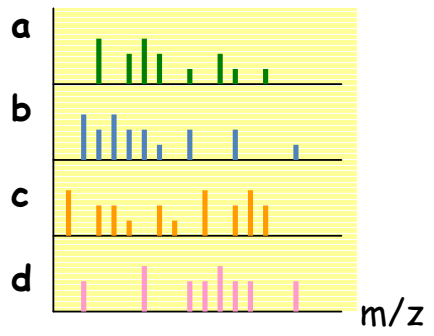

Figure 1 Identifying proteins via Proteomics-Mass Spectrometry. The mixture of proteins (or just one protein) must be digested to obtain peptides. The resulting peptides have to be cleaned and desalted via chromatography (e.g. POROS R2) to avoid salts and detergents, which artefact the MS analysis. Subsequently, the desalted and cleaned peptides are injected into the mass spectrometer. Finally, the matched peptides allow the identification of the proteins using databases (e.g. Mascot Server).

impact molecules. Furthermore, if these protein kinases to be studied contain PTMs, it is important to know that spatial and temporal factors can decrease the efficiency of our study (e.g. many kinases are regulated by phosphorylation of the activation loop, which then directly reflects cellular kinase activity).

Moreover, proteomics has been widely applied in various areas of science, ranging from the deciphering of molecular pathogenesis of diseases, the characterization of novel drug targets, to the discovery of potential diagnostic and prognostic biomarkers, where technology is capable of identifying and quantifying proteins associated with a particular disease by means of their altered levels of expression [72-74] and/or PTMs [75-77] between the control and disease states (e.g., biomarker candidates). This type of comparative (semi-quantitative) analysis enables correlations to be drawn between the range of proteins, their variations and modifications produced by a cell, tissue and biofluids and the initiation, progression, therapeutic monitoring or remission of a disease state.
PTMs including phosphorylation, glycosylation, acetylation and oxidation, in particular, have been of great interest in this field as they have been demonstrated as being linked to disease pathology and are useful targets for therapeutics.

In addition to MS-based large-scale protein and peptide sequencing, other innovative approaches including self-assembling protein microarrays [78] and bead-based flow cytometry $[79,80]$ to identify and quantify proteins and protein-protein interaction in a high throughput manner, have furthered our understanding of the molecular mechanisms involved in diseases.

Utilities of Matrix-assisted laser desorption/ionization tissue imaging MS

Matrix-assisted laser desorption/ionization (MALDI) tissue imaging mass spectrometry is particularly promising among the numerous applications of mass spectrometry. It is used for testing and analyzing the spatial arrangement of a wide range of molecules including proteins, peptides, lipids, drugs and metabolites, directly in thin 


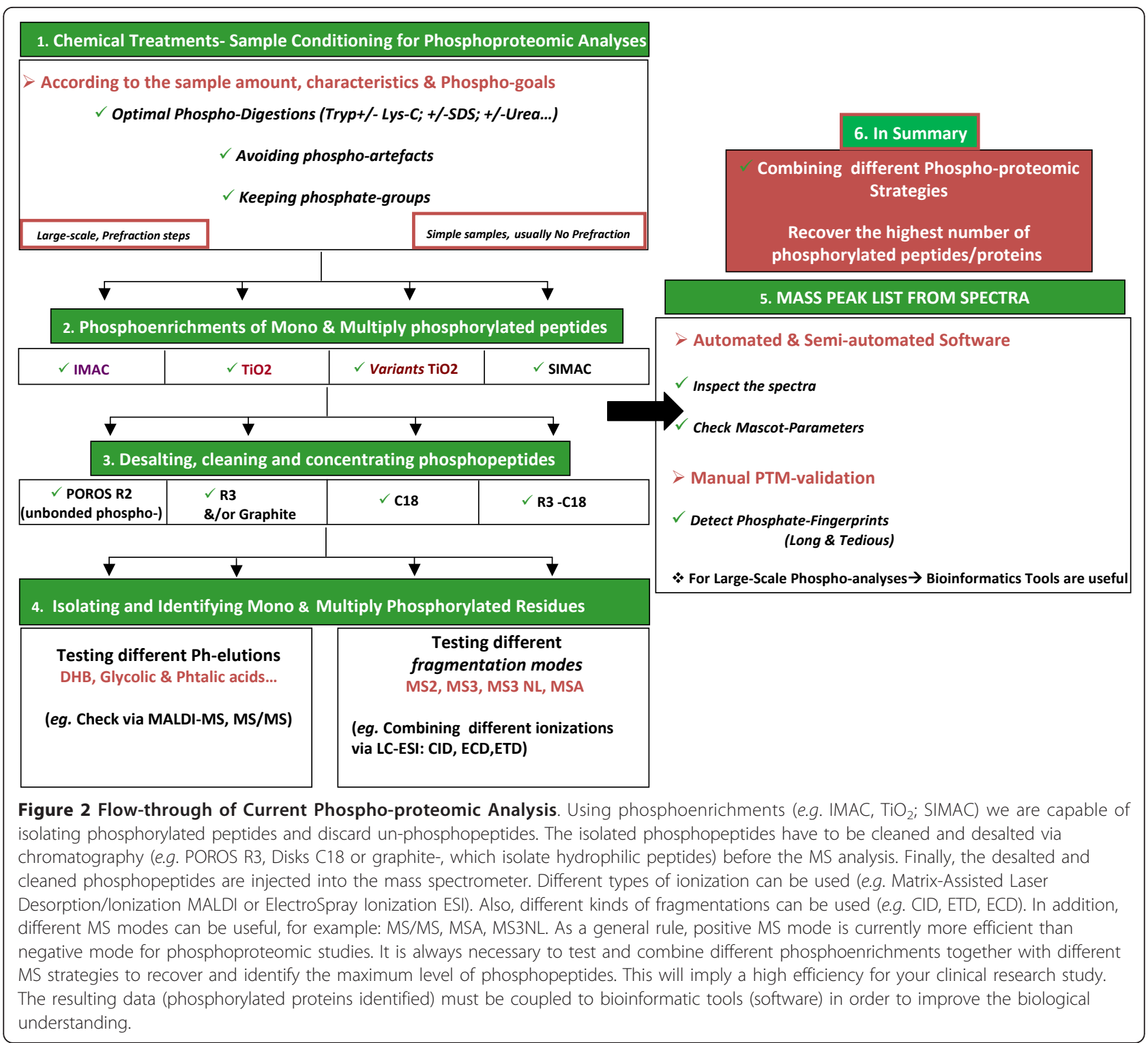

slices of tissue. In the field of proteomics, the technology avoids tedious and time-consuming extraction and fractionation steps classically required for sample analysis. Furthermore, MALDI imaging MS is increasingly recognized as a powerful method for clinical proteomics, particularly in cancer research. This recent technology has particular potential for the discovery of new tissue biomarker candidates, for classification of tumors, early diagnosis or prognosis, elucidating pathogenesis pathways and therapy monitoring. Over recent years, MALDI imaging MS has been used for molecular profiling and imaging directly in male and female reproductive tissues.

In summary, the wealth of advances in MS imaging will inevitably attract experts in OMICS (e.g. genomics, proteomics, bioinformatics) and clinicians, as the advantages and power of this technology become more widely known. In addition, it is important to point out for efficient clinical studies, that the identification of protein biomarkers in easily accessible biological fluids has potential for the development of minimally invasive procedures for early diagnostics, but the analysis of body fluids such as plasma, serum and urine is complicated by their wide dynamic range of protein expression, the variation in their composition and their sensitivity to sample handling [81-83].

\section{Concluding remarks and future needs}

Phosphoproteomics is a branch of proteomics that identifies, catalogs, and characterizes proteins containing a phosphate group as a PTM. Furthermore, phosphoproteomics 
provides clues on which protein or pathway might be activated because a change in phosphorylation status almost always reflects a change in protein activity. Indeed, it can indicate which proteins might be potential drug targets as exemplified by the kinase inhibitor. While phosphoproteomics will greatly expand knowledge about the numbers and types of phosphoproteins, its greatest promise is the rapid analysis of entire phosphorylation based signalling networks. Nevertheless, methodologies to enrich for phosphorylated residues from kinases should be improved, especially due to their low abundance of those signalling molecules within cells.

To summarize, clinical proteomics-MS has come a long way in the past decade in terms of technology/platform development, protein chemistry, and together with bioinformatics and other OMICS tools to identify molecular signatures of diseases based on protein pathways and signalling cascades. Hence, there is great promise for disease diagnosis, prognosis, and prediction of therapeutic outcome on an individualized basis. In addition, imaging MS will have a major impact in reproductive research by opening new avenues to the understanding of various molecular mechanisms and the diagnosis of reproductive pathologies. However, and as a general rule, without correct study design, strategy and implementation of robust analytical methodologies, the efforts, efficiency and expectations to make biomarkers (especially phosphorylated kinases) a useful reality in the near future, can easily be hampered.

\section{Author information}

EL PhD Scientist, -Hospital Universitario 12 de Octubre-, was a recipient of a Postdoc fellowship "Ministerio de Ciencia e Innovacion de España". And coordinates a Multidisciplinary Project "Red de Hospitales Nacionales de España" for Clinical OMICS Research, -Hospital Universitario Infantil Niño Jesús-.

SRM and JLP are MD PhD and hold a tenured position at Hospital Universitario 12 de Octubre.

LM is Professor at Universidad Autónoma Medicina de Madrid, and holds a tenured position at Hospital Universitario Infantil Niño Jesús.

\section{Acknowledgements}

Special thanks for the support from the International Society for Translational Medicine (http://www.istmed.org).

\section{Author details}

${ }^{1}$ Hospital Universitario Infantil Niño Jesús, Av. Menéndez Pelayo 65, 28009 Madrid, Spain ${ }^{2}$ Hospital Universitario 12 de Octubre, Av. De Córdoba s/n, 28040 Madrid, Spain ${ }^{3}$ Facultad de Medicina de la Universidad Autónoma de Madrid, C/del Arzobispo Morcillo, 428029, Spain

\section{Authors' contributions}

Authors EL SRM, JLP and LM carried out Clinical Proteomics-MS studies for this short-review, in order to develop future Clinical Proteomic-
Phosphoproteomic MS research studies and publish this article. All authors read and approved the final manuscript.

\section{Competing interests}

The authors declare that they have no competing interests.

Received: 23 February 2012 Accepted: 29 March 2012

Published: 29 March 2012

\section{References}

1. Lopez E, Wesselink JJ, Lopez I, Mendieta J, Gomez-Puertas P, RodriguezMuno S: Technical Phosphoproteomic and Bioinformatic Tools useful in Cancer Research. J Clin Bioinforma 2011, 1:26, doi:10.1186/2043-9113-1-26.

2. Dengjel J, Akimov V, Olsen JV, Bunkenborg J, Mann M, Blagoev B, Andersen JS: Quantitative proteomic assessment of very early cellular signalling events. Nat Biotechnol 2007, 25:566-568

3. Kruger M, Kratchmarova I, Blagoev B, Tseng YH, Kahn CR, Mann M: Dissection of the insulin signalling pathway via quantitative phosphoproteomics. Proc Natl Acad Sci USA 2008, 105:2451-2456.

4. Pan C, Olsen JV, Daub H, Mann M: Global effects of kinase inhibitors on signalling networks revealed by quantitative phosphoproteomics. $\mathrm{Mol}$ Cell Proteomics 2009, 8(12):2796-808.

5. Daub H, Olsen JV, Bairlein M, Gnad F, Oppermann FS, Korner R, Greff Z, Keri G, Stemmann O, Mann M: Kinase-selective enrichment enables quantitative phosphoproteomics of the kinome across the cell cycle. Mol Cell 2008, 31:438-448.

6. Mertins P, Eberl HC, Renkawitz J, Olsen JV, Tremblay ML, Mann M, Ullrich A, Daub $\mathrm{H}$ : Investigation of protein-tyrosine phosphatase 1B function by quantitative proteomics. Mol Cell Proteomics 2008, 7:1763-1777.

7. Hilger M, Bonaldi T, Gnad F, Mann M: Systems-wide analysis of a phosphatase knock down by quantitative proteomics and phosphoproteomics. Mol Cell Proteomics 2009, 8(8):1908-1920.

8. Dolado I, Nebreda AR: AKT and oxidative stress team up to kill cancer cells. Cancer Cell 2008, 14(6):427-429.

9. Malumbres M, Barbacid M: To cycle or not to cycle: a critical decision in cancer. Nat Rev Cancer 2001, 1(3):222-231.

10. Swat A, Dolado I, Rojas JM, Nebreda AR: Cell density-dependent inhibition of epidermal growth factor receptor signalling by p38alpha mitogenactivated protein kinase via Sprouty2 downregulation. $\mathrm{Mol} \mathrm{Cell}$ Biol 2009, 29(12):3332-3343.

11. Ventura JJ, Tenbaum S, Perdiguero E, Huth M, Guerra C, Barbacid M, Pasparakis M, Nebreda AR: p38alpha MAP kinase is essential in lung stem and progenitor cell proliferation and differentiation. Nat Genet 2007, 39(6):750-758.

12. Hulit J, Suyama K, Chung S, Keren R, Agiostratidou G, Shan W, Dong X, Williams TM, Lisanti MP, Knudsen K, Hazan RB: N-cadherin signalling potentiates mammary tumor metastasis via enhanced extracellular signal-regulated kinase activation. Cancer Res 2007, 67(7):3106-3116.

13. Chen LL, Ji Y, Xu JF, Lu SH, Hou YY, Hou J, Sujie A, Zeng HY, Tan YS: Focal nodular hyperplasia of liver: a clinicopathologic study of 238 patients. Zhonghua Bing Li Xue Za Zhi 2011, 40(1):17-22, Chinese.

14. Moro L, Arbini AA, Marra E, Greco M: Constitutive activation of MAPK/ERK inhibits prostate cancer cell proliferation through upregulation of BRCA2. Int J Oncol 2007, 30(1):217-224.

15. Zebisch A, Czernilofsky AP, Keri G, Smigelskaite J, Sill H, Troppmair J: Signalling through RAS-RAF-MEK-ERK: from basics to bedside. Curr Med Chem 2007, 14(5):601-623.

16. Matsuura K, Nohno Y, Hijiya N, Uchida T, Tsukamoto Y, Moriyama M: Extracellular signal-regulated protein kinase is activated in cervical intraepithelial neoplasms but inactivated in invasive cervical carcinoma. Pathol Int 2006, 56(7):368-374.

17. Gerke V, Moss SE: Annexins: from structure to function. Physiol Rev 2002 82(2):331-371.

18. Alldridge LC, Harris HJ, Plevin R, Hannon R, Bryant CE: The annexin protein lipocortin 1 regulates the MAPK/ERK pathway. J Biol Chem 1999, 274(53):37620-37628.

19. Sudo T, Hidaka H: Regulation of calcyclin (S100A6) binding by alternative splicing in the $\mathrm{N}$-terminal regulatory domain of annexin $\mathrm{XI}$ isoforms. J Biol Chem 1998, 273(11):6351-6357.

20. Araki R, Fukumura R, Fujimori A, Taya $Y$, Shiloh $Y$, Kurimasa A, Burma S, Li GC, Chen DJ, Sato K, Hoki Y, Tatsumi K, Abe M: Enhanced 
phosphorylation of p53 serine 18 following DNA damage in DNAdependent protein kinase catalytic subunit-deficient cells. Cancer Res 1999, 59(15):3543-3546.

21. McLachlin DT, Chait BT: Analysis of phosphorylated proteins and peptides by mass spectrometry. Curr Opin Chem Biol 2001, 5(5):591-602.

22. Ficarro SB, McCleland ML, Stukenberg PT, Burke DJ, Ross MM, Shabanowitz J, Hunt DF, White FM: Phosphoproteome analysis by mass spectrometry and its application to Saccharomyces cerevisiae. Nat Biotechnol 2002, 20(3):301-305.

23. Gruhler A, Olsen JV, Mohammed S, Mortensen P, Faergeman NJ, Mann M, Jensen ON: Quantitative phosphoproteomics applied to the yeast pheromone signalling pathway. Mol Cell Proteomics 2005, 4(3):310-327.

24. Pandey A, Fernandez MM, Steen H, Blagoev B, Nielsen MM, Roche S, Mann M, Lodish HF: Identification of a novel immunoreceptor tyrosinebased activation motif-containing molecule, STAM2, by mass spectrometry and its involvement in growth factor and cytokine receptor signalling pathways. J Biol Chem 2000, 275(49):38633-38639.

25. Mann M, Ong SE, Gronborg M, Steen H, Jensen ON, Pandey A: Analysis of protein phosphorylation using mass spectrometry: deciphering the phosphoproteome. Trends Biotechnol 2002, 20(6):261-268.

26. Larsen MR, Thingholm TE, Jensen ON, Roepstorff $P$, Jorgensen TJ: Highly selective enrichment of phosphorylated peptides from peptide mixtures using titanium dioxide microcolumns. Mol Cell Proteomics 2005, 4(7):873-886, Epub 2005 Apr 27.

27. Larsen MR, Cordwell SJ, Roepstorff P: Graphite powder as an alternative or supplement to reversed-phase material for desalting and concentration of peptide mixtures prior to matrix-assisted laser desorption/ionizationmass spectrometry. Proteomics 2002, 2(9):1277-1287.

28. Speicher K, Kolbas O, Harper S, Speicher DW: Systemic analysis of peptide recoveries from in gel digestion for protein identifications in proteome studies. J Biomol Tech 2000, 11:74-86.

29. Martin H, Flandez M, Nombela C, Molina M: Protein phosphatases in MAPK signalling: we keep learning from yeast. Mol Microbiol 2005, 58(1):6-16

30. Biemann K: Contributions of mass spectrometry to peptide and protein structure. Biomed Environ Mass Spectrom 1988, 16(1-12):99-111.

31. Roepstorff P, Fohlman J: Proposal for a common nomenclature for sequence ions in mass spectra of peptides. Biomed Mass Spectrom 1984, 11(11):601.

32. Steen $H$, Küster B, Mann M: Quadrupole time-of-flight versus triplequadrupole mass spectrometry for the determination of phosphopeptides by precursor ion scanning. J Mass Spectrom 2001, 36(7):782-790.

33. Steen $H$, Mann M: A new derivatization strategy for the analysis of phosphopeptides by precursor ion scanning in positive ion mode. J Am Soc Mass Spectrom 2002, 13(8):996-1003.

34. McLachlin DT, Chait BT: Improved beta-elimination-based affinity purification strategy for enrichment of phosphopeptides. Anal Chem 2003, 75:6826-6836.

35. Poot AJ, Ruijter E, Nuijens T, Dirksen EH, Heck AJ, Slijper M, Rijkers DT, Liskamp RM: Selective enrichment of Ser-/Thr-phosphorylated peptides in the presence of Ser-/Thr-glycosylated peptides. Proteomics 2006, 6:6394-6399.

36. Arrigoni $G$, Resjo $S$, Levander F, Nilsson $R$, Degerman $E$, Quadroni $M$ Pinna $L A$, James $P$ : Chemical derivatization of phosphoserine and phosphothreonine containing peptides to increase sensitivity for MALDIbased analysis and for selectivity of MS/MS analysis. Proteomics 2006, 6:757-766.

37. Xia Q, Cheng D, Duong DM, Gearing M, Lah JJ, Levey Al, Peng J: Phosphoproteomic analysis of human brain by calcium phosphate precipitation and mass spectrometry. J Proteome Res 2008, 7:2845-2851.

38. Bodenmiller B, Mueller LN, Mueller M, Domon B, Aebersold R: Reproducible isolation of distinct, overlapping segments of the phosphoproteome. Nat Methods 2007, 4:231-237.

39. Tao WA, Wollscheid B, O'Brien R, Eng JK, Li XJ, Bodenmiller B, Watts JD, Hood L, Aebersold R: Quantitative phosphoproteome analysis using a dendrimer conjugation chemistry and tandem mass spectrometry. Nat Methods 2005, 2:591-598.

40. López E, López I, Sequí J, Ferreira A: Discovering and validating unknown phospho-sites from p38 and HuR protein kinases in vitro by
Phosphoproteomic and Bioinformatic tools. J Clin Bioinforma 2011, 1(1):16.

41. Huddleston MJ, Annan RS, Bean MF, Carr SA: Selective detection of phosphopeptides in complex-mixtures by electrospray liquidchromatography mass-spectrometry. J Am Soc Mass Spectrom 1993, 4:710-717.

42. DeGnore JP, Qin J: Fragmentation of phosphopeptides in an ion trap mass spectrometer. J Am Soc Mass Spectrom 1998, 9:1175-1188.

43. Boersema PJ, Mohammed S, Heck AJ: Phosphopeptide fragmentation and analysis by mass spectrometry. J Mass Spectrom 2009, 44:861-878.

44. Beausoleil SA, Jedrychowski M, Schwartz D, Elias JE, Villen J, Li JX, Cohn MA, Cantley LC, Gygi SP: Large-scale characterization of HeLa cell nuclear phosphoproteins. Proc Natl Acad Sci USA 2004, 101:12130-12135.

45. Benschop JJ, Mohammed S, O'Flaherty M, Heck AJR, Slijper M, Menke FLH: Quantitative Phosphoproteomics of Early Elicitor Signalling in Arabidopsis. Mol Cell Proteomics 2007, 6:1198-1214

46. Schroeder MJ, Shabanowitz J, Schwartz JC, Hunt DF, Coon JJ: A Neutral Loss Activation Method for Improved Phosphopeptide Sequence Analysis by Quadrupole Ion Trap Mass Spectrometry. Anal Chem 2004, 76:3590-3598

47. López E, López I, Ferreira A, Sequí J: Clinical and technical phosphoproteomic research. Proteome Sci 2011, 9:27.

48. Molina H, Horn DM, Tang N, Mathivanan S, Pandey A: Global proteomic profiling of phosphopeptides using electron transfer dissociation tandem mass spectrometry. Proc Natl Acad Sci USA 2007, 104:2199-2204.

49. Chi A, Huttenhower C, Geer LY, Coon JJ, Syka JEP, Bai DL, Shabanowitz J, Burke DJ, Troyanskaya OG, Hunt DF: Analysis of phosphorylation sites on proteins from Saccharomyces cerevisiae by electron transfer dissociation (ETD) mass spectrometry. Proc Natl Acad Sci USA 2007, 104:2193-2198.

50. Mohammed S, Lorenzen K, Kerkhoven R, Breukelen Bv, Vannini A, Cramer P, Heck AJR: Multiplexed Proteomics Mapping of Yeast RNA Polymerase II and III Allows Near-Complete Sequence Coverage and Reveals Several Novel Phosphorylation Sites. Anal Chem 2008, 80:3584-3592.

51. Sweet SMM, Bailey CM, Cunningham DL, Heath JK, Cooper HJ: Large-scale localization of protein phosphorylation by use of electron capture dissociation mass spectrometry. Mol Cell Proteomics 2009, 8:904-912.

52. Hassanein M, Rahman JS, Chaurand P, Massion PP: Advances in proteomic strategies toward the early detection of lung cancer. Proc Am Thorac Soc 2011, 8(2):183-188

53. Anderson $\mathrm{L}$ : Candidate-based proteomics in the search for biomarkers of cardiovascular disease. J Physiol 2005, 563:23-60.

54. Rifai N, Gillette MA, Carr SA: Protein biomarker discovery and validation: the long and uncertain path to clinical utility. Nat Biotechnol 2006, 24:971-983.

55. García-Foncillas J, Bandrés E, Zárate R, Remírez N: Proteomic analysis in cancer research: potential application in clinical use. Clin Trans/ Oncol 2006, 8:250-261

56. Bouchal P, Roumeliotis T, Hrstka R, Nenutil R, Vojtesek B, Garbis SD: Biomarker discovery in low-grade breast cancer using isobaric stable isotope tags and two-dimensional liquid chromatography-tandem mass spectrometry (iTRAQ-2DLC-MS/MS) based quantitative proteomic analysis. J Proteome Res 2009, 8:362-373.

57. Wiener MC, Sachs JR, Deyanova EG, Yates NA: Differential mass spectrometry: a label-free LC-MS method for finding significant differences in complex peptide and protein mixtures. Anal Chem 2004, 76:6085-6096.

58. Geiger T, Cox J, Ostasiewicz P, Wisniewski JR, Mann M: Super-SILAC mix for quantitative proteomics of human tumor tissue. Nat Methods 2010, 7:383-385.

59. Anderson $\mathrm{L}$, Hunter $\mathrm{CL}$ : Quantitative mass spectrometric multiple reaction monitoring assays for major plasma proteins. Mol Cell Proteomics 2006, 5:573-588.

60. Wang $\mathrm{H}$, Wong $\mathrm{CH}$, Chin A, Kennedy J, Zhang Q, Hanash S: Quantitative serum proteomics using dual stable isotope coding and nano LC-MS/ MSMS. J Proteome Res 2009, 8:5412-5422.

61. Lee J, Soper SA, Murray KK: Microfluidic chips for mass spectrometrybased proteomics. J Mass Spectrom 2009, 44:579-593.

62. Pierobon M, Calvert V, Belluco C, Garaci E, Deng J, Lise M, Nitti D, Mammano E, De Marchi F, Liotta L, Petricoin E: Multiplexed cell signalling analysis of metastatic and nonmetastatic colorectal cancer reveals 
COX2-EGFR signalling activation as a potential prognostic pathway biomarker. Clin Colorectal Cancer 2009, 8:110-117.

63. Ramachandran N, Raphael JV, Hainsworth E, Demirkan G, Fuentes MG Rolfs A, Hu Y, LaBaer J: Next-generation high-density self-assembling functional protein arrays. Nat Methods 2008, 5:535-538.

64. Beirne P, Pantelidis P, Charles P, Wells AU, Abraham DJ, Denton CP, Welsh Kl, Shah PL, du Bois RM, Kelleher P: Multiplex immune serum biomarker profiling in sarcoidosis and systemic sclerosis. Eur Respir J 2009, 34:1376-1382.

65. Kelleher MT, Fruhwirth G, Patel G, Ofo E, Festy F, Barber PR, Ameer-Beg SM, Vojnovic B, Gillett C, Coolen A, Kéri G, Ellis PA, Ng T: The potential of optical proteomic technologies to individualize prognosis and guide rational treatment for cancer patients. Target Oncol 2009, 4:235-252.

66. Wang P, Whiteaker JR, Paulovich AG: The evolving role of mass spectrometry in cancer biomarker discovery. Cancer Biol Ther 2009, 8:1083-1094.

67. Whiteaker JR, Zhang H, Eng JK, Fang R, Piening BD, Feng LC, Lorentzen TD, Schoenherr RM, Keane JF, Holzman T, Fitzgibbon M, Lin C, Zhang H, Cooke K, Liu T, Camp DG, Anderson L, Watts J, Smith RD, Mclntosh MW, Paulovich AG: Head-to-head comparison of serum fractionation techniques. J Proteome Res 2007, 6:828-836.

68. Ernoult E, Bourreau A, Gamelin E, Guette C: A proteomic approach for plasma biomarker discovery with iTRAQ labeling and OFFGEL fractionation. J Biomed Biotechnol 2010, 2010:927917, Epub 2009 Nov 1.

69. Nirmalan NJ, Hughes C, Peng J, McKenna T, Langridge J, Cairns DA, Harnden P, Selby PJ, Banks RE: Initial development and validation of a novel extraction method for quantitative mining of the formalin-fixed, paraffin-embedded tissue proteome for biomarker investigations. J Proteome Res 2010, 10:896-906.

70. Krishhan W, Khan IH, Luciw PA: Multiplexed microbead immunoassays by flow cytometry for molecular profiling: basic concepts and proteomics applications. Crit Rev Biotechnol 2009, 29:29-43.

71. Cha S, Imielinski MB, Rejtar T, Richardson EA, Thakur D, Sgroi DC, Karger BL: In situ proteomic analysis of human breast cancer epithelial cells using laser capture microdissection: annotation by protein set enrichment analysis and gene ontology. Mol Cell Proteomics 2010, 9:2529-2544.

72. Anderson KS, Sibani S, Wallstrom G, Qiu J, Mendoza EA, Raphael J, Hainsworth E, Montor WR, Wong J, Park JG, Lokko N, Logvinenko T, Ramachandran N, Godwin AK, Marks J, Engstrom P, Labaer J: Protein microarray signature of autoantibody biomarkers for the early detection of breast cancer. J Proteome Res 2011, 10:85-96.

73. Bateman NW, Sun M, Hood BL, Flint MS, Conrads TP: Defining central themes in breast cancer biology by differential proteomics: conserved regulation of cell spreading and focal adhesion kinase. J Proteome Res 2010, 9:5311-5324.

74. Kristiansen TZ, Harsha HC, Grønborg M, Maitra A, Pandey A: Differential membrane proteomics using 180-labeling to identify biomarkers for cholangiocarcinoma. J Proteome Res 2008, 7:4670-4677.

75. An HJ, Lebrilla CB: A glycomics approach to the discovery of potential cancer biomarkers. Methods Mol Biol 2010, 600:199-213.

76. Choudhary C, Mann M: Decoding signalling networks by mass spectrometry-based proteomics. Nat Rev Mol Cell Biol 2010, 11:427-439.

77. Madian AG, Regnier FE: Profiling carbonylated proteins in human plasma. J Proteome Res 2010, 9:1330-1343.

78. Iwabata H, Yoshida M, Komatsu Y: Proteomic analysis of organ-specific post-translational lysine-acetylation and -methylation in mice by use of anti-acetyllysine and -methyllysine mouse monoclonal antibodies. Proteomics 2005, 5:4653-4664.

79. Ceroni A, Sibani S, Baiker A, Pothineni VR, Bailer SM, LaBaer J, Haas J, Campbell CJ: Systematic analysis of the IgG antibody immune response against varicella zoster virus (VZV) using a self-assembled protein microarray. Mol Biosyst 2010, 6:1604-1610.

80. Wong J, Sibani S, Lokko NN, LaBaer J, Anderson KS: Rapid detection of antibodies in sera using multiplexed self-assembling bead arrays. $J$ Immunol Methods 2009, 350:171-182.

81. McDonnell LA, Corthals GL, Willems SM, van Remoortere A, van Zeijl RJ, Deelder AM: Peptide and protein imaging mass spectrometry in cancer research. J Proteomics 2010, 73:1921-1944.

82. Seeley EH, Caprioli RM: MALDI imaging mass spectrometry of human tissue: method challenges and clinical perspectives. Trends Biotechnol 2011, 29:136-143.
83. Hays JL, Kim G, Giuroiu I, Kohn EC: Proteomics and ovarian cancer: integrating proteomics information into clinical care. J Proteomics 2010, 73:1864-1872

doi:10.1186/2001-1326-1-2

Cite this article as: López et al:: Relevant phosphoproteomic and mass spectrometry: approaches useful in clinical research. Clinical and Translational Medicine 2012 1:2.

\section{Submit your manuscript to a SpringerOpen ${ }^{\mathcal{O}}$ journal and benefit from:}

- Convenient online submission

- Rigorous peer review

- Immediate publication on acceptance

- Open access: articles freely available online

- High visibility within the field

- Retaining the copyright to your article

Submit your next manuscript at $\boldsymbol{\Delta}$ springeropen.com 